Research article

\title{
Morphological and horticultural diversity of plum varieties evaluated under Kashmir conditions
}

\author{
Dinesh Kumar $^{1,2}$, K. K. Srivastava ${ }^{2}$ and S. R. Singh ${ }^{2}$ \\ ${ }^{1}$ ICAR-Central Institute of Temperate Horticulture, Srinagar, Jammu and Kashmir, India \\ ${ }^{2}$ Division of Crop Production, ICAR-Central Institute for Subtropical Horticulture, Lucknow, India \\ *Corresponding Author: dkches@ rediffmail.com \\ [Accepted: 22 April 2018]
}

\begin{abstract}
This study was carried out to evaluate the morphological and horticultural diversity among 15 plum varieties grafted on seedling rootstocks at ICAR-Central Institute for Temperate Horticulture, Srinagar, Jammu and Kashmir during 2013 and 2014. The highest Trunk cross sectional area $\left(177.37 \mathrm{~cm}^{2}\right)$ was recorded in Santa Rosa and canopy volume $\left(25.42 \mathrm{~m}^{3}\right)$ in AuRosa. The maximum fruit yield $\left(57.91 \mathrm{~kg} \mathrm{tree}^{-1}\right.$ ) was recorded in Meriposa and productivity efficiency $\left(0.785 \mathrm{~kg} \mathrm{~cm}^{-2}\right)$ was in Au-cherry. Highest fruit and pulp weight $(58.59 \mathrm{~g}$ and $56.49 \mathrm{~g}$ ) was recorded in Grand Duke and lowest seed weight $(0.74 \mathrm{~g})$ in Monarch. The highest length and width ratio (1.42) was recorded in Grand Duke and lowest (0.94) in Black Amber. The fruit quality attributes such as TSS $\left(21.10^{\circ} \mathrm{B}\right)$ was estimated in Santa Rosa and acidity $(0.69 \%)$ was in $\mathrm{Au}-$ cherry and Red Beauty cultivars. The varieties Au-Cherry, Meriposa, Tarkol, Beauty and Monark performed better in respect to yield and Grand Duke, Santa Rosa and Methley were better for fruit quality of plum under Kashmir conditions.
\end{abstract}

Keywords: Morphological - Pomological - Diversity - Plum - Varieties.

[Cite as: Kumar D, Srivastava KK \& Singh SR (2018) Morphological and horticultural diversity of plum varieties evaluated under Kashmir conditions. Tropical Plant Research 5(1): 77-82]

\section{INTRODUCTION}

Plum (Prunus domestica L.) is one of the important temperate fruit crops of India mainly grown in the state of Himachal Pradesh, Jammu and Kashmir, Uttarakhand, Punjab and Uttar Pradesh. The total area under plum cultivation is 22000 ha with annual production of 82000 tonnes and productivity is $3.72 \mathrm{t} \mathrm{ha}^{-1}$ (Anonymous 2015-16). The low productivity because of region specific suitable high-yielding varieties, production and protection technologies suiting to particular climatic conditions. The plum fruit are commonly used for fresh as well as for drying purposes. The processed products include candy, frozen fruit, jams, jelly products and traditional Serbian plum for alcoholic beverages (Milosevic et al. 2010). The ripe fruits are the rich source of Vitamin A, B (Thiamine), riboflavin and minerals like calcium, phosphorus and iron. The dried plums are known as prunes and all plum cultivar cannot be used for drying purpose. The prunes have great Ayurvedic value for medicine. European plum is used both for drying and fresh markets, while Chinese plums are used mainly for fresh market. In India, different plum varieties are Meriposa, Au-cherry, Tarkol, Beauty, Monarch, Green Gauge, Methley, Au-Rosa, Frontier, Kanto-05, Santal Rosa, Red Beauty, Grand Duke and President plum are high yielder and suitable for cultivation in India (Kumar et al. 2016a). Soil macro and micro nutrient play an important role in productivity and quality of plum (Sidhu \& Kaundal 2005, Milosevic et al. 2009). In plum, some cultivar requires low chill hours are suitable for plain area of Uttar Pradesh and Punjab and others variety requires high chill hours are suitable for hilly state like Himachal Pradesh, Jammu and Kashmir and Uttarakhand. In order to improve productivity, an experiment was under taken to evaluate the cultivars for specific traits under Kashmir conditions.

\section{MATERIALS AND METHODS}

A field experiment was conducted during the year 2013 and 2014 at the ICAR-Central Institute of Temperate Horticulture, Srinagar, Jammu and Kashmir. The Research farm is situated at latitude of $34^{\circ} 05^{\prime} \mathrm{N}$, 
longitude of $74^{\circ} 50^{\prime} \mathrm{E}$ and altitude of 1640 masl. The soil of experimental field was sandy clay loam having $0.45 \%$ organic carbon, $375.14 \mathrm{~kg} \mathrm{~N}, 10.45 \mathrm{~kg} \mathrm{P}$ and $251.24 \mathrm{~kg} \mathrm{~K} \mathrm{ha}^{-1}$. The varieties under evaluation was Meriposa, Au-cherry, Tarkol, Beauty, Monarch, Green Gauge, Methley, Au-Rosa, Frontier, Kanto-05, Santal Rosa, Red Beauty, Grand Duke and President plum laid out in Randomised Block Design with three replication. The trees were trained on modified central leader system and applied uniform standard cultural practices to all the trees under observations. The plum varieties grafted on seedling root stocks and planted $4 \mathrm{~m} \mathrm{x}$ $4 \mathrm{~m}$ spacing accommodating 625 plants per ha. The climatic conditions of the site falls under temperate region having cold conditions and peak during December and January and total average annual precipitation was about $700 \mathrm{~mm}$.

For performance evaluation, individual varieties were marked in the field and observations on growth, yield and quality were recorded. The trunk cross sectional area was calculated by using formula $\mathrm{TCSA}^{-\mathrm{Girth}^{2} / 4 \pi}$ (Westwood \& Roberts 1970). Plant height along with canopy spread were measured in east-west and northsouth direction and expressed in meter. Canopy volume was calculated the formula as described by Castle's (1983), Canopy volume $=0.5228 \times$ canopy height $(\mathrm{m}) \times$ canopy diameter $\left(\mathrm{m}^{2}\right)$. Canopy volume was recorded after harvesting the crop every year during the course of study. The fruits were harvested at the time of maturity of each year (2013 and 2014). Ten ripe fruits from each genotype were randomly selected for recording the observations on fruit quality traits. The data were collected on fruit length, width ( $\mathrm{mm})$, weight $(\mathrm{g})$, pulp weight $(\mathrm{g})$, stone weight $(\mathrm{g})$, TSS $\left({ }^{\mathrm{o}}\right.$ Brix), acidity (\%) and fruit yield $\left(\mathrm{kg}^{\mathrm{g}}\right.$ tree $\left.{ }^{-1}\right)$. The fruit weight was measured by digital balance of accuracy of $0.001 \mathrm{~g}$. The length and diameter of the fruit was measured with digital vernier calipers. The measurement of fruit length was made on the polar axis, i.e. between the apex and the end of stem. The maximum width of the fruit, as measured in the direction perpendicular to the polar axis, is defined as the diameter. After measuring the whole fruit size, the stone was manually separated from the fruits, and traits were measured. The fruit quality parameters such as Total soluble solids (TSS) was estimated by hand refractometer $\left(0-32^{\circ}\right.$ Brix $)$ after crushing the fruit pulp with a pestle and mortar and then squeezed through muslin cloth for extraction of juice. The titratable acidity was determined by titrating $2 \mathrm{ml}$ juice against N/10 sodium hydroxide using phenolphthalein as an indicator and expressed in Percent. The data of each year were analysed statistically as per the method suggested by Gomez \& Gomez (1984) for interpretation of results.

\section{RESULTS}

Vegetative growth

Data on trunk cross sectional area (TCSA) and canopy volume as influenced different varieties in plum (Table 1). Maximum TCSA $\left(165.42 \mathrm{~cm}^{2}\right.$ and $177.31 \mathrm{~cm}^{2}$ ) were recorded in Santa Rosa variety closely followed by Frontier $\left(148.68 \mathrm{~cm}^{2}\right.$ and $\left.160.80 \mathrm{~cm}^{2}\right)$ and Methley $\left(124.56 \mathrm{~cm}^{2}\right.$ and $\left.134.47 \mathrm{~cm}^{2}\right)$ respectively, during 2013 and 2014. The variety Santa Rosa was at par with variety Frontier and significantly superior to all other varieties. The mean maximum TCSA $\left(171.37 \mathrm{~cm}^{2}\right)$ was recorded in Santa Rosa variety followed by Frontier variety of plum. The canopy volume of the different plum varieties varied from 6.25 to $24.38 \mathrm{~m}^{3}$ and 8.12 to

Table 1. Performance of different plum varieties for Trunk Cross Sectional Area (TCSA) and canopy volume.

\begin{tabular}{|c|c|c|c|c|c|c|c|}
\hline \multirow{2}{*}{ S.No. } & \multirow{2}{*}{ Varieties } & \multicolumn{2}{|c|}{ TCSA $\left(\mathrm{cm}^{2}\right)$} & \multirow{2}{*}{ Mean } & \multicolumn{2}{|c|}{ Canopy volume $\left(\mathrm{m}^{3}\right)$} & \multirow{2}{*}{ Mean } \\
\hline & & 2013 & 2014 & & 2013 & 2014 & \\
\hline 1 & Meriposa & 99.87 & 110.87 & 105.37 & 6.25 & 8.12 & 7.19 \\
\hline 2 & Au-cherry & 53.45 & 63.33 & 58.39 & 14.99 & 16.87 & 15.93 \\
\hline 3 & Tarkol & 87.24 & 96.52 & 91.88 & 10.56 & 12.63 & 11.60 \\
\hline 4 & Beauty & 83.56 & 94.76 & 89.16 & 12.22 & 14.31 & 13.26 \\
\hline 5 & Monarch & 69.87 & 78.20 & 74.04 & 11.33 & 13.31 & 12.32 \\
\hline 6 & Green Gage & 84.63 & 93.75 & 89.19 & 17.16 & 19.25 & 18.21 \\
\hline 7 & Methley & 124.56 & 134.47 & 129.52 & 16.89 & 18.95 & 17.92 \\
\hline 8 & Black Amber & 74.82 & 83.63 & 79.23 & 9.22 & 11.25 & 10.24 \\
\hline 9 & Au-Rosa & 118.28 & 129.67 & 123.97 & 24.38 & 26.45 & 25.42 \\
\hline 10 & Frontier & 148.68 & 160.80 & 154.74 & 12.61 & 14.75 & 13.68 \\
\hline 11 & Kanto-05 & 91.23 & 102.03 & 96.63 & 9.81 & 11.85 & 10.83 \\
\hline 12 & Santa Rosa & 165.42 & 177.31 & 171.37 & 20.66 & 22.67 & 21.67 \\
\hline 13 & Red Beauty & 66.58 & 77.39 & 71.99 & 6.92 & 8.98 & 7.95 \\
\hline 14 & Grand Duke & 89.26 & 100.59 & 94.93 & 13.82 & 15.75 & 14.79 \\
\hline \multirow[t]{2}{*}{15} & President Plum & 65.89 & 74.35 & 70.12 & 12.02 & 14.15 & 13.09 \\
\hline & CD at $5 \%$ & 20.24 & 21.546 & - & 7.21 & 7.27 & - \\
\hline
\end{tabular}

www.tropicalplantresearch.com 
$26.45 \mathrm{~m}^{3}$ during 2013 and 2014. Maximum canopy volume $\left(24.38 \mathrm{~m}^{3}\right.$ and $\left.26.45 \mathrm{~m}^{3}\right)$ were recorded in variety Au-Rosa followed by Santa Rosa $\left(20.66 \mathrm{~m}^{3}\right.$ and $\left.22.67 \mathrm{~m}^{3}\right)$ and Green Gage $\left(17.16 \mathrm{~m}^{3}\right.$ and $\left.19.25 \mathrm{~m}^{3}\right)$, respectively during 2013 and 2014.

Fruit yield and productivity efficiency

Fruit yield and productivity efficiency as influenced by different varieties in plum (Table 2). Maximum fruit yield $\left(47.65 \mathrm{~kg}\right.$ tree $\left.^{-1}\right)$ was recorded in the variety Meriposa followed by Beauty $\left(35.83 \mathrm{~kg} \mathrm{tree}^{-1}\right)$ and Tarkol (33.84 kg tre $\mathrm{e}^{-1}$ ), respectively during 2013. Slightly improvement in yield was recorded in Meriposa (43.04\%) followed by Au-cherry (79.68\%) and Tarkol (72.90\%) during 2014. The mean maximum fruit yield $(57.91 \mathrm{~kg}$ tree $^{-1}$ ) was recorded in Meriposa followed by Au-cherry (46.68 $\left.\mathrm{kg} \mathrm{tree}^{-1}\right)$ and Tarkol (46.18 kg tree ${ }^{-1}$ ), varieties respectively. The productivity efficiency as influenced by different varieties in plum, maximum productivity efficiency ( $0.624 \mathrm{~kg} \mathrm{~cm}^{-2}$ TCSA) followed by Meriposa ( $0.477 \mathrm{~kg} \mathrm{~cm}^{-2}$ TCSA) and Monarch $\left(0.462 \mathrm{~kg} \mathrm{~cm}^{-2}\right.$ TCSA), respectively during 2013. Slightly improvement in productivity efficiency of Au-cherry (51.76\%) followed by Monarch $(50.86 \%)$ and Meriposa $(28.72 \%)$, respectively during 2014 . The mean maximum productivity efficiency was recorded in Au-cherry $\left(0.785 \mathrm{~kg} \mathrm{~cm}^{-2}\right.$ TCSA) followed by Monarch $\left(0.579 \mathrm{~kg} \mathrm{~cm}^{-2}\right.$ TCSA) and Meriposa $\left(0.543 \mathrm{~kg} \mathrm{~cm}^{-2}\right.$ TCSA) respectively.

Table 2. Performance of different plum varieties for fruit yield and productivity efficiency.

\begin{tabular}{|c|c|c|c|c|c|c|c|}
\hline \multirow[t]{2}{*}{ S.No. } & \multirow{2}{*}{ Varieties } & \multicolumn{2}{|c|}{$\begin{array}{c}\text { Fruit yield } \\
\left(\text { kg tree }^{-1}\right)\end{array}$} & \multirow[t]{2}{*}{ Mean } & \multicolumn{2}{|c|}{$\begin{array}{c}\text { Productivity efficiency } \\
\left(\mathrm{kg} \mathrm{cm}^{-2} \text { TCSA }\right)\end{array}$} & \multirow[t]{2}{*}{ Mean } \\
\hline & & 2013 & 2014 & & 2013 & 2014 & \\
\hline 1. & Meriposa & 47.65 & 68.16 & 57.91 & 0.477 & 0.614 & 0.543 \\
\hline 2. & Au-cherry & 33.38 & 59.98 & 46.68 & 0.624 & 0.947 & 0.785 \\
\hline 3. & Tarkol & 33.84 & 58.51 & 46.18 & 0.387 & 0.606 & 0.496 \\
\hline 4. & Beauty & 35.83 & 53.17 & 44.50 & 0.428 & 0.561 & 0.495 \\
\hline 5. & Monarch & 32.28 & 54.52 & 43.40 & 0.462 & 0.697 & 0.579 \\
\hline 6. & Green Gage & 27.23 & 40.80 & 34.02 & 0.322 & 0.435 & 0.379 \\
\hline 7. & Methley & 13.22 & 51.58 & 32.40 & 0.106 & 0.383 & 0.245 \\
\hline 8. & Black Amber & 9.01 & 48.38 & 28.70 & 0.120 & 0.578 & 0.349 \\
\hline 9. & Au-Rosa & 23.19 & 22.81 & 23.00 & 0.196 & 0.175 & 0.186 \\
\hline 10. & Frontier & 10.29 & 34.50 & 22.40 & 0.069 & 0.214 & 0.142 \\
\hline 11. & Kanto-05 & 22.69 & 19.30 & 20.99 & 0.248 & 0.189 & 0.219 \\
\hline 12. & Santa Rosa & 24.03 & 17.55 & 20.79 & 0.145 & 0.099 & 0.122 \\
\hline 13. & Red Beauty & 10.38 & 28.07 & 19.22 & 0.155 & 0.362 & 0.259 \\
\hline 14. & Grand Duke & 22.61 & 8.55 & 15.58 & 0.253 & 0.085 & 0.169 \\
\hline \multirow[t]{2}{*}{15.} & President Plum & 27.03 & 3.15 & 15.09 & 0.410 & 0.042 & 0.226 \\
\hline & CD at $5 \%$ & 9.45 & 11.27 & - & 0.187 & 0.225 & - \\
\hline
\end{tabular}

Fruit quality characters

A perusal of data on fruit weight, stone weight and pulp weight as influenced by different varieties in plum (Table 3). Maximum fruit weight (57.46 g) was recorded in Tarkol variety followed by Meriposa (57.43 g) and Santa Rosa (55.80 g), respectively during 2013. Whereas, Grand Duke registered highest fruit weight $(65.83 \mathrm{~g})$ followed by Santa Rosa (56.61 g) and President Plum (55.59 g), respectively in 2014. Mean maximum fruit weight $(58.59 \mathrm{~g})$ was recorded in Grand Duke followed by Santa Rosa $(56.21 \mathrm{~g})$ and Tarkol $(55.08 \mathrm{~g})$, respectively. Minimum stone weight $(0.73 \mathrm{~g})$ was recorded in Black Amber followed by Methley $(0.88 \mathrm{~g})$ and Red Beauty $(0.88 \mathrm{~g})$ during 2013. Whereas, Methley registered lowest seed weight $(0.60 \mathrm{~g})$ among all the varieties during 2014. Mean lowest seed weight $(0.74 \mathrm{~g})$ was recorded in Methley followed by Black Amber $(0.78 \mathrm{~g})$ and Monarch $(0.86 \mathrm{~g})$, respectively. Highest pulp weight $(56.17 \mathrm{~g})$ was recorded in Tarkol followed by Meriposa (55.85 g) and Santa Rosa (54.42 g), respectively during 2013. In 2014, maximum pulp weight (63.26 g) was registered in Grand Duke followed by Santa Rosa (54.77 g) and President plum (52.97 g), respectively. Mean maximum pulp weight $(56.49 \mathrm{~g})$ was recorded in Grand Duke followed by Santa Rosa $(54.60 \mathrm{~g})$ and Tarkol (53.45 g), respectively.

Fruit size as influenced by different varieties in plum (Table 4). Highest fruit length $(56.28 \mathrm{~mm}$ and 64.04 $\mathrm{mm}$ ) was recorded in Grand Duke followed by President plum $(51.15 \mathrm{~mm}$ and $55.63 \mathrm{~mm})$ were recorded in 2013 and 2014. Maximum fruit width $(45.99 \mathrm{~mm})$ in Santa Rosa followed by Tarkol $(45.56 \mathrm{~mm})$ in 2013 whereas, in 2014 Frontier registered maximum fruit width $(46.45 \mathrm{~mm})$ followed by President plum (46.35 $\mathrm{mm})$. The highest length and width ratio (1.39 and 1.44) was recorded in Grand Duke followed by President 
plum (1.22 and 1.20) in 2013 and 2014.

Table 3. Performance of different plum varieties for fruit, pulp and stone weight.

\begin{tabular}{|c|c|c|c|c|c|c|c|c|c|c|}
\hline \multirow{2}{*}{ S.No. } & \multirow{2}{*}{ Varieties } & \multicolumn{2}{|c|}{ Fruit weight (g) } & \multirow{2}{*}{ Mean } & \multicolumn{2}{|c|}{ Stone weight (g) } & \multirow{2}{*}{ Mean } & \multicolumn{2}{|c|}{ Pulp weight (g) } & \multirow{2}{*}{ Mean } \\
\hline & & 2013 & 2014 & & 2013 & 2014 & & 2013 & 2014 & \\
\hline 1. & Meriposa & 57.43 & 50.30 & 53.87 & 1.58 & 1.57 & 1.58 & 55.85 & 48.73 & 52.29 \\
\hline 2. & Au-cherry & 26.17 & 27.63 & 26.90 & 1.49 & 1.03 & 1.26 & 24.68 & 26.60 & 25.64 \\
\hline 3. & Tarkol & 57.46 & 52.71 & 55.08 & 1.29 & 1.99 & 1.64 & 56.17 & 50.72 & 53.45 \\
\hline 4. & Beauty & 49.41 & 46.41 & 47.91 & 1.34 & 0.60 & 0.97 & 48.07 & 45.81 & 46.94 \\
\hline 5. & Monarch & 28.87 & 33.80 & 31.34 & 0.87 & 0.84 & 0.86 & 28.0 & 32.96 & 30.48 \\
\hline 6. & Green Gage & 18.68 & 19.31 & 18.99 & 1.47 & 1.54 & 1.51 & 17.21 & 17.77 & 17.49 \\
\hline 7. & Methley & 15.57 & 24.16 & 19.86 & 0.88 & 0.60 & 0.74 & 14.69 & 23.56 & 19.13 \\
\hline 8. & Black Amber & 27.72 & 26.31 & 27.01 & 0.73 & 0.82 & 0.78 & 26.99 & 25.49 & 26.24 \\
\hline 9. & Au-Rosa & 54.61 & 44.72 & 49.66 & 1.89 & 2.27 & 2.08 & 52.72 & 42.45 & 47.58 \\
\hline 10. & Frontier & 48.40 & 53.90 & 51.15 & 1.68 & 2.42 & 2.05 & 46.72 & 51.48 & 49.10 \\
\hline 11. & Kanto-05 & 42.69 & 33.60 & 38.15 & 1.44 & 0.75 & 1.10 & 41.25 & 32.85 & 37.05 \\
\hline 12. & Santa Rosa & 55.80 & 56.61 & 56.21 & 1.38 & 1.84 & 1.61 & 54.42 & 54.77 & 54.60 \\
\hline 13. & Red Beauty & 47.37 & 50.12 & 48.75 & 0.88 & 0.86 & 0.87 & 46.49 & 49.26 & 47.88 \\
\hline 14. & Grand Duke & 51.36 & 65.83 & 58.59 & 1.64 & 2.57 & 2.11 & 49.72 & 63.26 & 56.49 \\
\hline \multirow[t]{2}{*}{15.} & President Plum & 52.74 & 65.59 & 59.16 & 3.62 & 2.62 & 3.12 & 49.12 & 62.97 & 56.05 \\
\hline & CD at $5 \%$ & 16.14 & 18.27 & - & 1.02 & 0.97 & - & $\mathbf{1 7 . 1 2}$ & 19.54 & - \\
\hline
\end{tabular}

Table 4. Performance of different plum varieties for fruit size and L/W ratio.

\begin{tabular}{|c|c|c|c|c|c|c|c|}
\hline \multirow[t]{2}{*}{ S.No. } & \multirow[t]{2}{*}{ Varieties } & \multicolumn{2}{|c|}{$\begin{array}{c}\text { Fruit size (mm) } \\
2013\end{array}$} & \multirow{2}{*}{$\begin{array}{r}\text { Ratio } \\
(\mathrm{L} / \mathrm{W})\end{array}$} & \multicolumn{2}{|c|}{$\begin{array}{c}\text { Fruit size (mm) } \\
2014\end{array}$} & \multirow[t]{2}{*}{$\begin{array}{r}\text { Ratio } \\
(\mathbf{L} / \mathbf{W})\end{array}$} \\
\hline & & Length & Width & & Length & Width & \\
\hline 1. & Meriposa & 44.01 & 45.45 & 0.97 & 37.28 & 40.63 & 0.92 \\
\hline 2. & Au-cherry & 37.15 & 35.32 & 1.05 & 36.97 & 35.29 & 1.05 \\
\hline 3. & Tarkol & 42.59 & 45.56 & 0.93 & 44.94 & 44.01 & 1.02 \\
\hline 4. & Beauty & 43.76 & 42.77 & 1.02 & 29.87 & 31.37 & 0.95 \\
\hline 5. & Monarch & 37.83 & 36.85 & 1.03 & 36.15 & 32.78 & 1.10 \\
\hline 6. & Green Gage & 32.06 & 31.15 & 1.03 & 32.18 & 29.64 & 1.08 \\
\hline 7. & Methley & 28.96 & 29.28 & 0.99 & 29.56 & 27.56 & 1.07 \\
\hline 8. & Black Amber & 34.33 & 38.75 & 0.89 & 35.10 & 35.23 & 0.99 \\
\hline 9. & Au-Rosa & 48.04 & 45.35 & 1.06 & 59.10 & 53.41 & 1.11 \\
\hline 10. & Frontier & 46.51 & 44.62 & 1.04 & 48.83 & 46.45 & 1.05 \\
\hline 11. & Kanto-05 & 40.76 & 40.70 & 1.00 & 28.19 & 27.25 & 1.03 \\
\hline 12. & Santa Rosa & 43.42 & 45.99 & 0.94 & 48.82 & 45.85 & 1.06 \\
\hline 13. & Red Beauty & 36.19 & 34.86 & 1.04 & 46.82 & 45.11 & 1.04 \\
\hline 14. & Grand Duke & 56.28 & 40.38 & 1.39 & 64.04 & 44.53 & 1.44 \\
\hline 15. & President Plum & 51.15 & 42.25 & 1.22 & 55.63 & 46.35 & 1.20 \\
\hline & CD at $5 \%$ & 8.78 & 6.23 & - & 8.24 & 6.41 & - \\
\hline
\end{tabular}

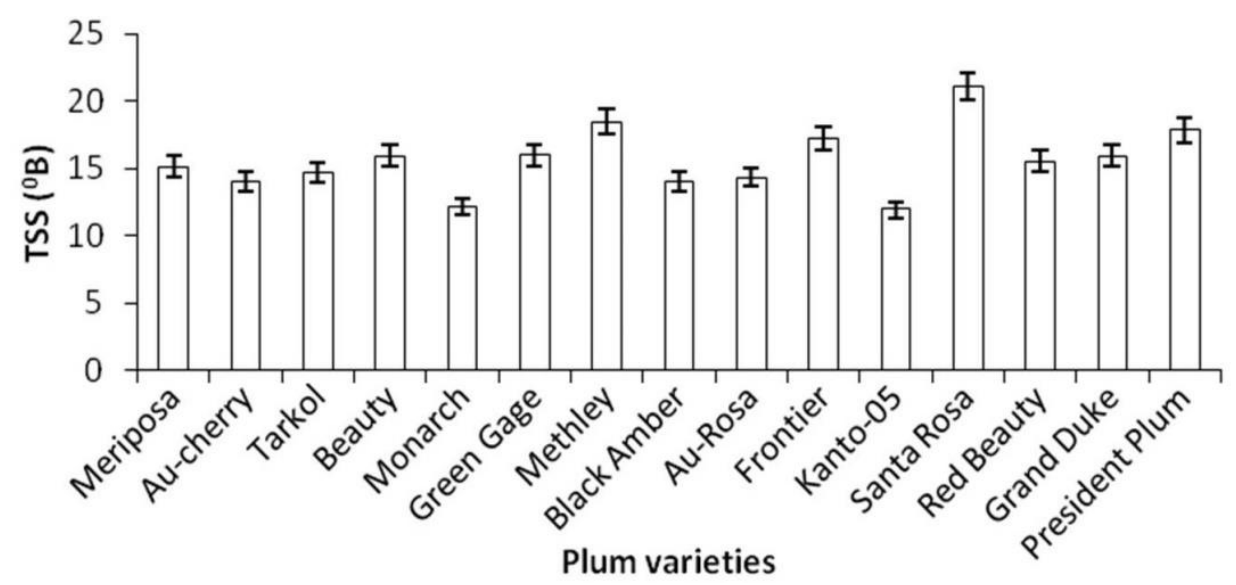

Figure 1. TSS as influenced by different varieties in plum. 
The pooled data for two years on fruit quality character as influenced by different varieties in plum (Fig. 1 \& 2). Mean maximum Total Soluble Solids content $\left(21.1^{\circ} \mathrm{B}\right)$ was recorded in Santa Rosa followed by Methley $\left(18.47^{\circ} \mathrm{B}\right)$ and Frontier $\left(17.28^{\circ} \mathrm{B}\right)$, respectively. Fruit acidity varies $(0.44$ to $0.69 \%)$ in different varieties of plum. Maximum fruit acidity $(0.69 \%)$ was recorded in Au-cherry and Red Beauty, whereas, minimum $(0.44 \%)$ was recorded in Methley variety of plum.

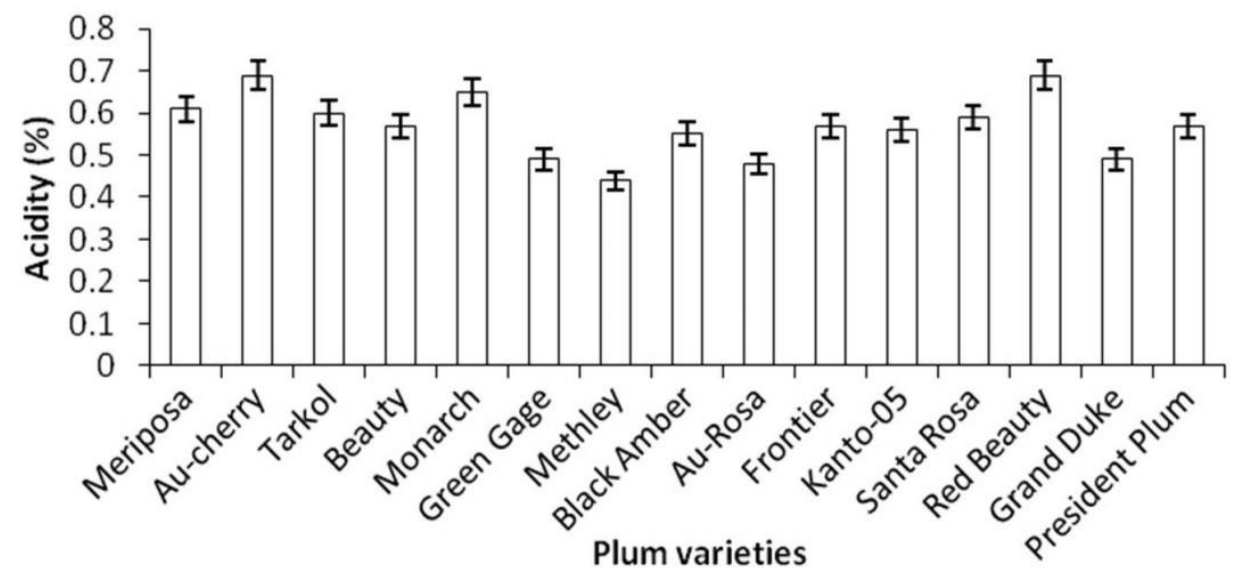

Figure 2. Fruit acidity as influenced by different varieties in plum.

\section{DISCUSSION}

Vegetative growth

In the present investigation results of 15 plum varieties for morphological and pomological diversity revealed that maximum trunk cross sectional area was recorded in Santa Rosa variety and canopy volume in AuRosa variety might be due to heredity characters of variety performing well under favourable climatic conditions. This result is in agreement with a previous study by Kumar et al. (2016a) who found lot of variations in morphological characters in plum varieties grown in Kashmir region. The growth behaviour of plum depends on varietal characters and environmental conditions of the region (Sosna 2002, Vitanova et al. 2004).

\section{Fruit yield and productivity efficiency}

The Au-cherry, Meriposa, Tarkol, Beauty and Monarch varieties of plum performed better in respect to fruit yield and productivity efficiency due to favourable soil and climatic conditions which increases the uptake of nutrients from root to aerial part of the plants for better fruit yield and productivity efficiency. These results are in accordance with the finding of Kumar et al. (2015, 2016a, b) while working on plum and apricot under Kashmir conditions. The maximum fruit weight in Grand Duke, Santa Rosa and Tarkol might be due to favourable soil and environmental condition during fruit growth and developmental stages of theses varieties. Whereas, maximum fruit size was recorded in Grand Duke and President plum might be due to genetical characters of these varieties and favourable climatic conditions for proper fruit growth. Meland (2005) reported that fruit size depends on location of fruits on trees in plum.

\section{Fruit quality}

The fruit quality characters viz., TSS and acidity, maximum TSS was recorded in Santa Rosa and Methley might be due to varietal character and environmental conditions favours for improvement in TSS content. Whereas, higher acidity was recorded in Au-cherry variety might be due to heredity character of the variety and environmental conditions favours for improvement in acidity content.

\section{CONCLUSION}

The present study can be concluded that the varieties Au-cherry, Meriposa, Tarkol, Beauty and Monarch performed better in respect to fruit yield and productivity efficiency. Whereas, the varieties Grand Duke, Santa Rosa and Methley were better for Fruit quality traits under Kashmir conditions.

\section{ACKNOWLEDGEMENTS}

The authors are grateful to The Director ICAR-CITH, Srinagar, Jammu and Kashmir for providing the financial and technical assistance for undertaking the experiment. 


\section{REFERENCES}

Anonymous (2015-16) Area and Production of Horticultural Crops-All India

Castle's, W (1993) Growth, yield and cold hardness of seven year old 'Bearss' lemon on twenty seven root stocks. Proceeding of Florida State Horticultural Society 9: 23-25.

Gomez KA \& Gomez AA (1984) Statistical Procedures for Agricultural Research, $2^{\text {nd }}$ edition. John Wiley and Sons Inc., New York.

Kumar D, Lal S \& Ahmed N (2015) Morphological and pomological diversity among apricot (Prunus armeniaca) genotypes grown in India. Indian Journal of Agricultural Sciences 85(10): 1349-1355.

Kumar D, Lal S \& Ahmed N (2016a) Genetic diversity among plum genotypes in North west Himalayan region of India. Indian Journal of Agricultural Sciences 86(5): 666-672.

Kumar D, Singh DB, Srivastava KK, Singh SR \& Zargar KA (2016b) Performance of apricot varieties/genotypes in north western Himalayan region of India. SAARC Journal of Agriculture 14(2): 107116.

Meland M (2005) High density planting systems of European plums - the effect of growth and productivity of three cultivars after nine years. Acta Agriculturae Scandinavica, Section B - Soil and Plant Science 55: 5157.

Milosevic T, Glisic I \& Milosevic N (2009) Dense planting effect on the productive capacity of some plum cultivars. Acta Horticulturae 825: 485-490.

Milosevic T, Milosevic N \& Mratinic E (2010) Morphogenic variability of some autochthonous plum cultivars in western Serbia. Brazilian Archives of Biology and Technology 53: 1293-1297.

Sidhu LS \& Kaundal GS (2005) Effect of planting density on fruit yield, foliar nutrient content and root distribution of plum (Prunus salicina Lindl.) cv. Satluj Purple. Acta Horticulturae 696: 299-302.

Sosna I (2002) Growth and cropping of four plum cultivars on different rootstocks in South Western Poland. Journal of Fruit and Ornamental Plant Research 10: 95-103.

Vitanova I, Dimkova S \& Ivanova D (2004) Vegetative and reproductive parameters of introduced plum cultivars. Journal of Fruit and Ornamental Plant Research 12: 257-262.

Westwood M N \& Roberts A N (1970) The relationship between trunk cross sectional area and weight of apple tree. Journal of American Society for Horticultural Science 95: 28-30. 